\title{
Notes on the vocalizations of Cloud Cisticola (Cisticola textrix)
}

\section{Peter Boesman}

In the following we briefly analyze and compare voice of the different races of Cloud Cisticola (Cisticola textrix). We also try to quantify the extent of any vocal differences using the criteria proposed by Tobias et al. (2010), as a support for taxonomic review.

We have made use of sound recordings available on-line from Xeno Canto (XC) and Macaulay Library (ML), and of additional recordings kindly forwarded to us by Guy Gibbon.

Song is given during aerial display, and consists of a few jhigh-pitched whistles followed by some ticking notes. Comparison of song between races:
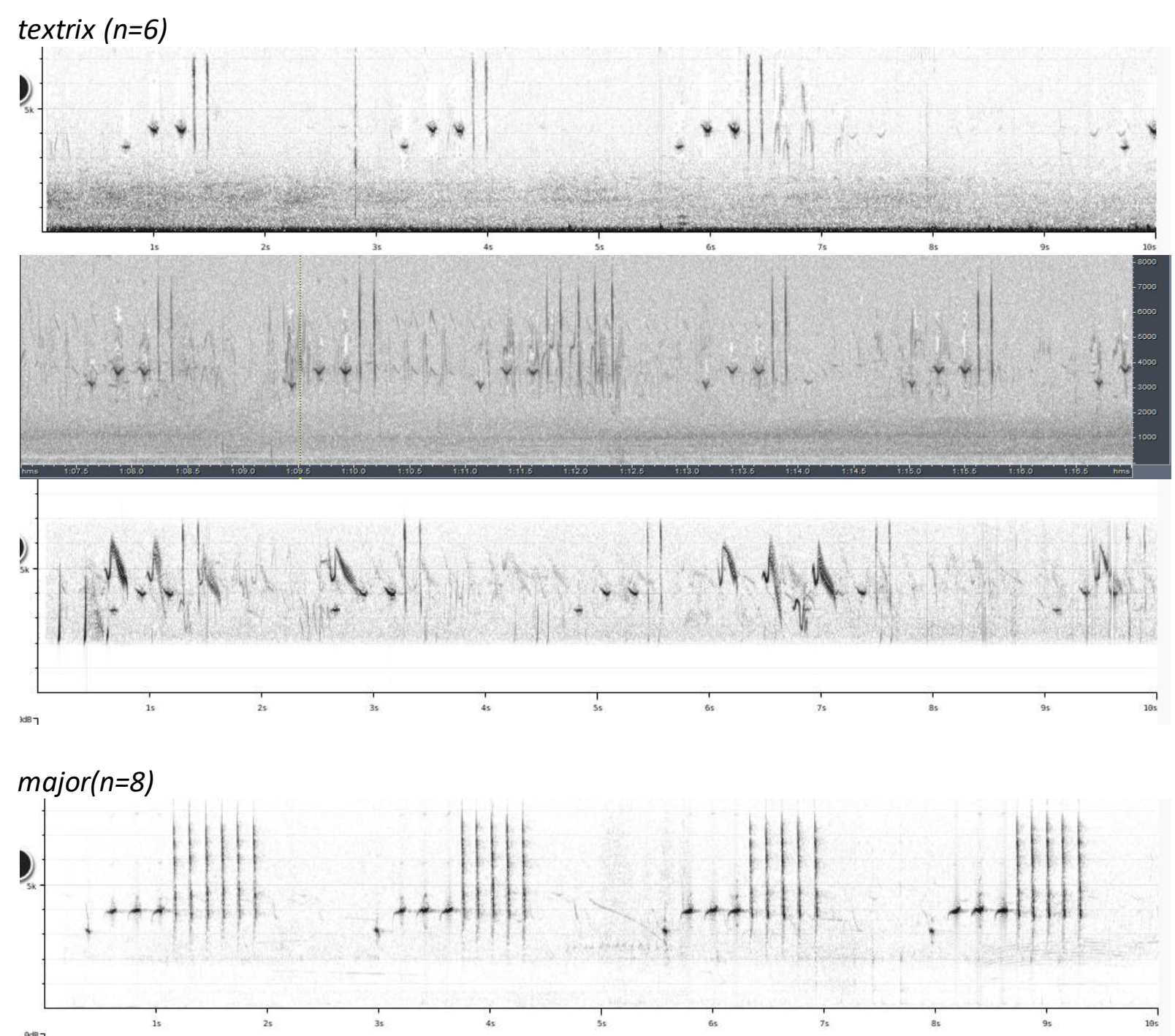

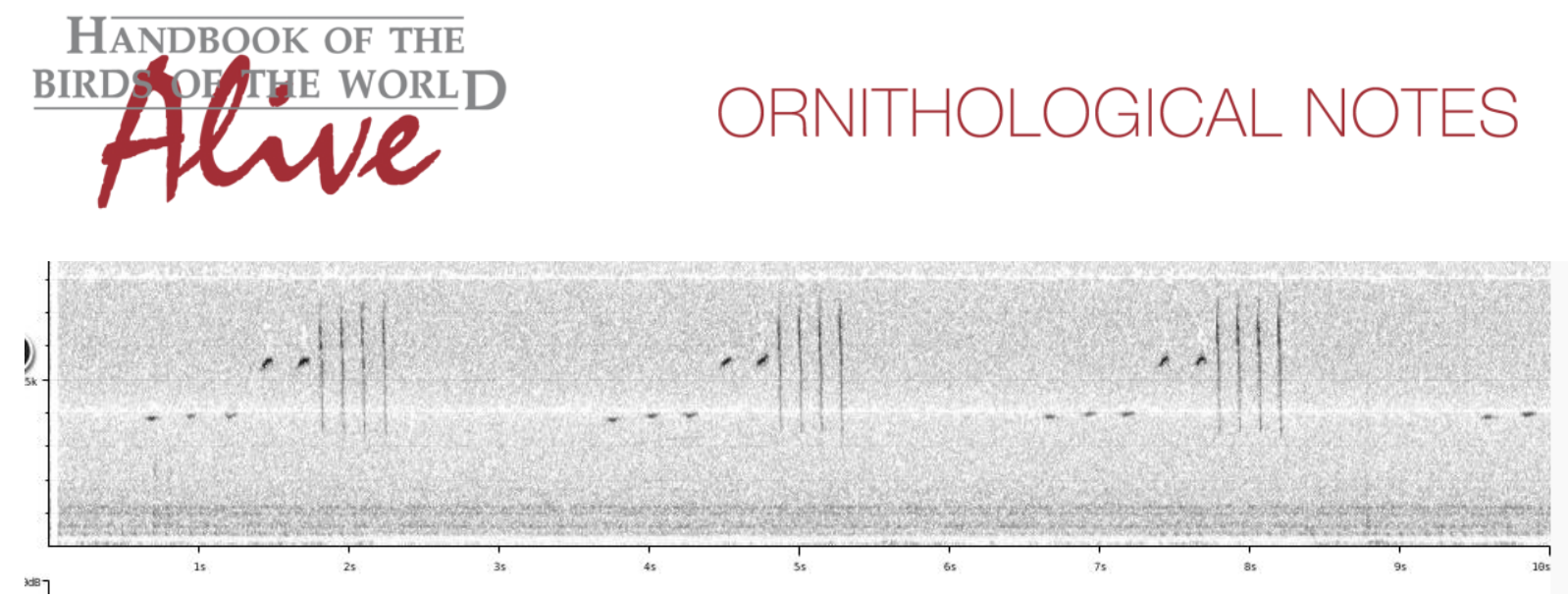

Song of both races is structurally similar. The available examples of tetrix (of different dates and places) do have however exactly the same pattern: 1 lower-pitched note +2 higherpitched notes $+2-4$ ticking notes.

Song of major/marley seems to have more notes. In the available examples we found following series (lower-pitched note + higher-pitched notes + ticking notes):

$0+3+3$ or more ticking notes

$0+4+3$ or more ticking notes

$1+3+5$ or 6 ticking notes

$2+2+3$ or 4 ticking notes

$3+2+4$ or 5 ticking notes (most common)

There are no available recordings of the other two races.

While the $1+2$ notes (+2-4 ticking notes) seems to be unique for textrix, it is clear that there is quite some variability in the note series of major/marley. It is likely that with increasing number of recordings some overlap may be found.

Based on total number of (non-ticking) notes (3 for textris vs. 3-5 for other races) or pattern of the note series, a score for vocal difference of 1-2 could be given.

This note was finalized on 11th April 2016, using sound recordings available on-line at that moment. We would like to thank in particular the sound recordists: Peter Boesman, Sander Bot, Tim Cockcroft, Guy Gibbon, Charles Hesse, Catriona Leven, Linda Macaulay, Doug Norman and Lynette Rudman.

\section{References}

Tobias, J.A., Seddon, N., Spottiswoode, C.N., Pilgrim, J.D., Fishpool, L.D.C. \& Collar, N.J. (2010). Quantitative criteria for species delimitation. Ibis 152(4): 724-746.

\section{Recommended citation}

Boesman, P. (2016). Notes on the vocalizations of Cloud Cisticola (Cisticola textrix). HBW Alive Ornithological Note 226. In: Handbook of the Birds of the World Alive. Lynx Edicions, Barcelona. (retrieved from http://www. hbw.com/node/932187 on 28 September 2016). 